\title{
Characterisation of Isolates of Tilletia indica Inciting Karnal Bunt of Wheat (Triticum aestivum L.)
}

\author{
Jagmohan Singh*, Rashmi Aggarwal, M.S. Gurjar, Sapana Sharma and M.S. Saharan
}

Division of Plant Pathology, ICAR-Indian Agricultural Research Institute, New Delhi-110012, India

*Corresponding author

\begin{abstract}
A B S T R A C T
Keywords

Tilletia indica,

Karnal Bunt,

Triticum aestivum

Article Info

Accepted:

15 November 2018

Available Online:

10 December 2018

Wheat is the most important food crop in India. During 2017-18, India's harvesting recorded wheat grain production $99.70 \mathrm{mt}$ from $29.58 \mathrm{mha}$ cultivated area. India's participation in the international wheat trade however is not up to the mark as being a major wheat producer. One of the major constraints in exporting wheat is prevalence of Karnal bunt (KB), internationally quarantined disease in the Indo-gangetic plain, major wheat bowl of the country. Karnal bunt caused by Tilletia indica (Mitra) is heterothallic fungus which requires fusion of different mating types for causing infection which results variants in their different potential to cause disease. Keeping this in view present study was undertaken to characterize different isolates of $T$. indica on the basis of mycelial growth, mycelial weight and sporulation. It was observed that there was non-significant variation in mycelial growth and mycelial weight, but significant variation in sporulation was observed among various isolates of $T$. indica. $\mathrm{KB} 1$ and $\mathrm{KB} 2$ isolates were most sporulating as compared to other isolates of $T$. indica. Characterization of Tilletia indica isolates will help in understanding the mechanism(s) of pathogenesis for devising novel strategies for management of Karnal bunt of wheat.
\end{abstract}

\section{Introduction}

Wheat (Triticum aestivum) is the most prominently cereal crop grown worldwide (Haung and Roder, 2004), and a basic staple food for human population. After the green revolution, wheat production has increased abundantly. Currently, India has surplus stock of wheat and a potential to generate more surplus. India has produced $99.70 \mathrm{mt}$ wheat from 29.58 mha cultivated area in 201718. The prevalence of the Karnal bunt (KB) disease in Northern-western plain zone of India, is barrier on wheat grain export due to the Sanitary and Phytosanitary agreement, such as restricted movement of consignment to other countries (FAO, 1996). Karnal bunt or partial bunt of wheat caused by the heterotallic fungus Tilletia indica (syn. Neovossiaindica) was first reported from Karnal (Haryana) by Mitra (Mitra, 1931). T. indica is a heterothallic fungus belonging to the order Ustilaginales and family Ustilaginaceae (Nagarajan et al., 1997). 
Seventy-seven countries had imposed restrictions on import of wheat from the areas where the $\mathrm{KB}$ disease occurs (Bonde et al., 2004).

The wheat importing countries have imposed strict quarantine measures and insist on zero tolerance limit (Singh and Gogoi, 2011). In recent years, re-emergence of $\mathrm{KB}$ disease in North-western plains of India had seriously affected quality of wheat grain (Gurjar et al., 2016). Karnal Bunt is seed and soil-borne and also has an air-borne sporidial stage. The fungus enters the grain through the germinal end and partially converts the kernels into sori filled with teliospores (Aggarwal et al., 1999). $T$. indica survives in the form of diploid teliospores in or on the seed and in agricultural soil.

Teliospores of $T$. indicagerminate to produce primary sporidia or the macro (filiform) conidia are splash dispersed and in turn produce a large quantity of secondary or micro or allantoid spores (Bansal et al., 1983). These spores are the only form that infects the wheat earhead (Dhaliwal and Singh, 1988).

T. indica being heterothallic fungus demands fusion between secondary sporidia of opposite mating types that results in much variation (Duran and Cromaty, 1977). Keeping this in view the studies were conducted undertaken to characterize different isolates of $T$. indicaon the basis of mycelial growth, mycelial weight and sporulation.

\section{Materials and Methods}

\section{Host and pathogen}

Twenty isolates of $T$. indica were cultured and maintained at $16 \pm 2{ }^{0} \mathrm{C}$ in incubator in Fungal and Molecular Biology Laboratory, Division of Plant Pathology, ICAR-IARI, New Delhi for further use (Table 1).

\section{Comparison of radial mycelial growth of $T$. indica}

Potato dextrose agar media was sterilized and poured in $90 \mathrm{~mm}$ petriplates. All isolates were inoculated in three petri plates with using a disc of culture bearing germinating spores and incubated at $16 \pm 2{ }^{\circ} \mathrm{C}$ in BOD incubator under light and dark conditions. After few days, creamy white growth of fungus appeared. The diameter of fungus colony was measured using scale after 20 days of inoculation and was analysed statistically (Fig. 1).

\section{Comparison of sporulation}

A culture disc facing downward was placed at the apical part of the PDA slant and the tubes were incubated at $16 \pm 2 \mathrm{C}$ with alternate light and darkness. After 7 to 8 days creamy white growth of fungus appeared showering sporidia downward from the disc which covered the entire slant within a few days. Spore suspension for all 20 isolates using 20 days old slant cultures was used for allentoid spore count through haemocytometer. Allantiod spore of banana shape were infective spores in T. indica (Fig. 2). The three replicated data observed on sporulation of all the isolates of T. indica was statistically analysed (Fig. 3).

\section{Comparison of mycelial weight}

Sterilized potato dextrose broth was suspended in $250 \mathrm{ml}$ sterilized conical flasks. The media was inoculated with all the KB isolates using mycelial bits and incubated at $16 \pm 2{ }^{\circ} \mathrm{C}$ in BOD incubator under light and dark conditions.

Fungal mat was thus harvested on $20^{\text {th }}$ day and filtered through muslin cloth. Fungal mycelium fresh from each flask was weighed using electrical weighing balance. Three replicates were kept for each isolate and was statistically analysed. 


\section{Results and Discussion}

Comparison of radial mycelial growth of $T$. indica isolates

Data recorded on radial mycelial growth of $T$. indica isolates is presented in Table 2. Among 20 isolates, $\mathrm{KB} 1, \mathrm{~KB} 2, \mathrm{~KB} 8, \mathrm{~KB} 16, \mathrm{~KB} 17$ and KB18 had significantly higher radial mycelial growth, with no significant difference between them. Minimum mycelial radial growth was observed in isolate KB19 $(1.20 \mathrm{~cm})$.

\section{Isolates of $T$. indica and sporulation}

The data on sporulation (allantoid spores) of different isolates of $T$. indica was recorded, statistically analyzed, and is presented in Table 2. Among 20 isolates, KB1 $\left(32 \times 10^{4}\right.$ spores $/ \mathrm{ml})$ and $\mathrm{KB} 2\left(30.33 \times 10^{4}\right.$ spores $\left./ \mathrm{ml}\right)$ were significantly highly sporulative, with no significant difference between them. Isolate KB13 and KB14 were least sporulative $\left(0.22 \times 10^{4}\right.$ spores $\left./ \mathrm{ml}\right)$.

\section{Mycelial weight of $T$. indica isolates}

Data recorded on mycelial weight of the isolates of $T$. indica is presented in Table 2. Mycelial weight was also significantly higher in $\mathrm{KB} 1$ (3.28gm) and $\mathrm{KB} 2$ (2.90gm), with no significant difference between them. Minimum mycelial weight was observed in isolates $\mathrm{KB} 15$ (0.14 gm).

Taking into consideration all above three parameters, KB1 isolate showing highest sporulation count, radial mycelial growth and mycelial weight, was selected for further expression studies.

Table.1.Isolates of T.indica collected from North-Western plain zone of India

\begin{tabular}{|c|l|l|l|}
\hline S. No. & Isolates & Location & Year of collection \\
\hline 1. & KB-1 & Aligarh, UP & 2015 \\
\hline 2. & KB-2 & New Delhi & 2015 \\
\hline 3. & KB-3 & Taroari, Karnal, Haryana & 2014 \\
\hline 4. & KB-4 & Pipli, Kurukshetra, Haryana & 2014 \\
\hline 5. & KB-5 & Nilokheri, Karnal, Haryana & 2014 \\
\hline 6. & KB-6 & Sonipat, Haryana & 2014 \\
\hline 7. & KB-7 & Jind, Haryana & 2014 \\
\hline 8. & KB-8 & Panipat, Haryana & 2014 \\
\hline 9. & KB-9 & Bareilly, UP & 2015 \\
\hline 10. & KB-10 & Bhiwani, Haryana & 2015 \\
\hline 11. & KB-11 & Pundri, Kaithal, Haryana & 2015 \\
\hline 12. & KB-12 & Ambala, Haryana & 2015 \\
\hline 13. & KB-13 & Pantnagar, Uttarakhand & 2015 \\
\hline 14. & KB-14 & Sultanpur, UP & 2015 \\
\hline 15. & KB-15 & Allahabad, UP & 2015 \\
\hline 16. & KB-16 & Bulandshahr, UP & 2016 \\
\hline 17. & KB-17 & Saharanpur, UP & 2016 \\
\hline 18. & KB-18 & Mujaffar Nagar, UP & 2016 \\
\hline 19. & KB-19 & Pataudi, Gurgaon, Haryana & 2016 \\
\hline 20. & KB-20 & Shamli, Haryana & 2016 \\
\hline
\end{tabular}


Figure.1 Radial mycelial growth of $20 \mathrm{~KB}$ (Karnal Bunt) isolates
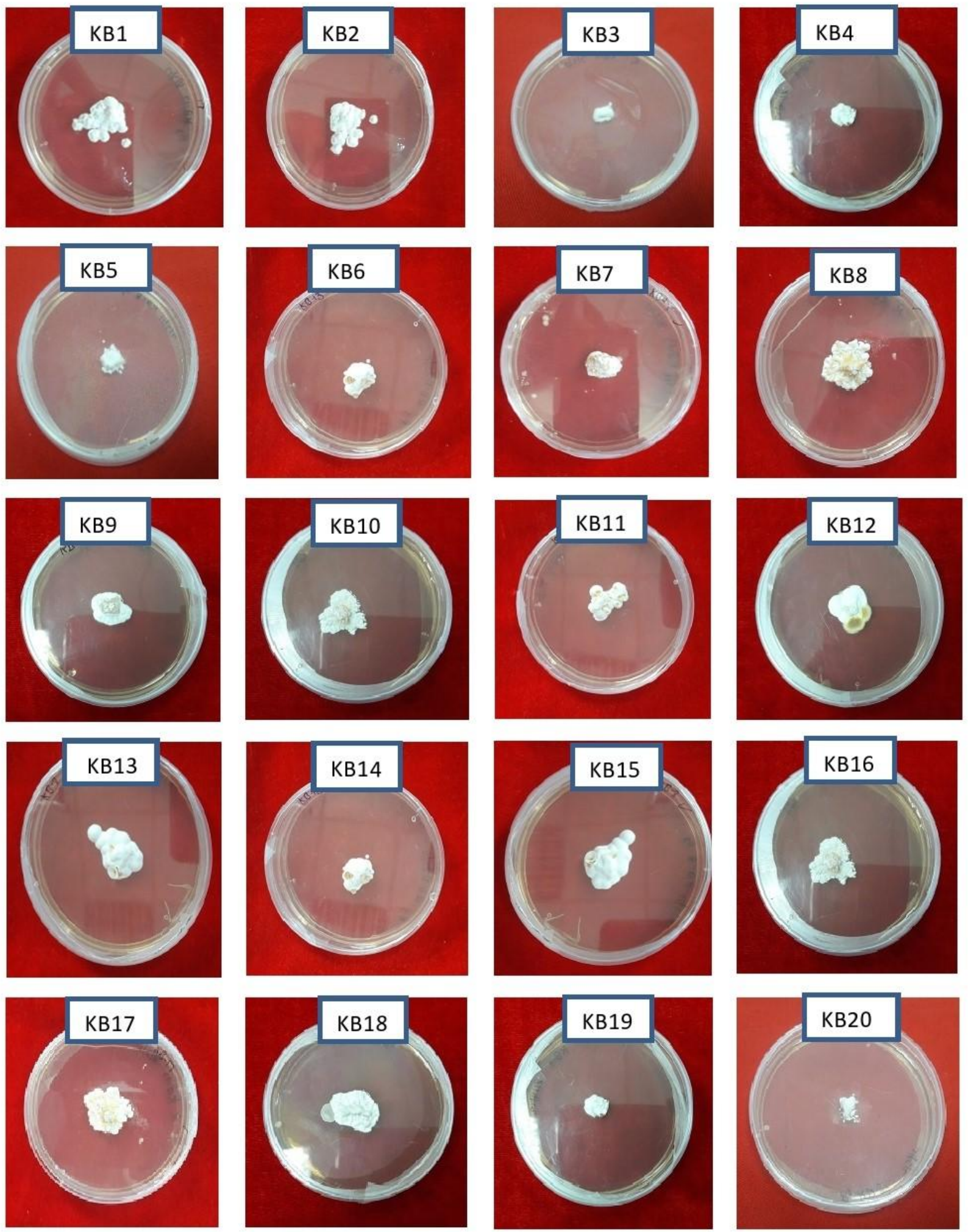
Table.2 Radial mycelial growth, sporulation and mycelial weight of KB isolates

\begin{tabular}{|l|c|c|c|}
\hline T. indica isolates & $\begin{array}{c}\text { Average } \\
(\mathrm{cm})\end{array}$ & $\begin{array}{c}\text { Average } \\
\left.\left(10^{4} \text { Spores }\right)^{-1}\right)\end{array}$ & $\begin{array}{c}\text { Average } \\
(\mathrm{gm})\end{array}$ \\
\hline KB1 & 2.79 & 32.00 & 3.28 \\
\hline KB2 & 2.78 & 30.33 & 2.90 \\
\hline KB3 & 1.50 & 3.67 & 1.43 \\
\hline KB4 & 1.45 & 2.78 & 1.40 \\
\hline KB5 & 1.56 & 7.56 & 1.32 \\
\hline KB6 & 1.62 & 6.56 & 1.88 \\
\hline KB7 & 1.68 & 1.66 & 0.86 \\
\hline KB8 & 2.80 & 6.89 & 1.98 \\
\hline KB9 & 1.60 & 14.00 & 2.10 \\
\hline KB10 & 1.80 & 18.78 & 0.78 \\
\hline KB11 & 1.76 & 21.67 & 2.52 \\
\hline KB12 & 1.87 & 16.22 & 0.41 \\
\hline KB13 & 1.84 & 0.22 & 0.38 \\
\hline KB14 & 1.78 & 0.22 & 0.14 \\
\hline KB15 & 1.75 & 2.11 & 1.72 \\
\hline KB16 & 2.69 & 16.78 & 2.22 \\
\hline KB17 & 2.78 & 17.11 & 2.21 \\
\hline KB18 & 2.76 & 2.33 & 1.11 \\
\hline KB19 & 1.20 & 2.89 & 0.29 \\
\hline KB20 & 1.30 & 2.04 & 4.24 \\
\hline C.D. & 0.16 & 0.12 & 2.09 \\
\hline SE(m) & 0.06 & 0.04 & \\
\hline SE(d) & 0.08 & 0.06 & 4.56 \\
\hline C.V. & 4.81 & & \\
\hline & & & \\
\hline
\end{tabular}

Figure.2 Microscopic view of allantiod spores of Tilletiaindica

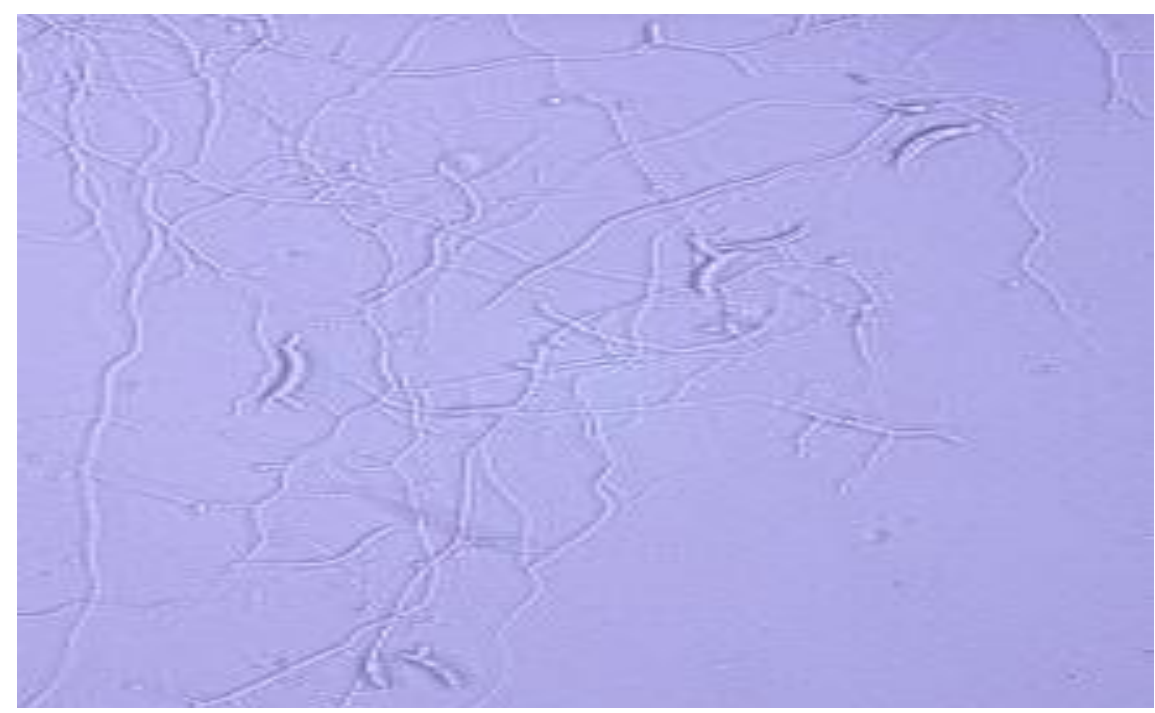


Figure.3 Sporulation of $20 \mathrm{~KB}$ (Karnal bunt) isolates
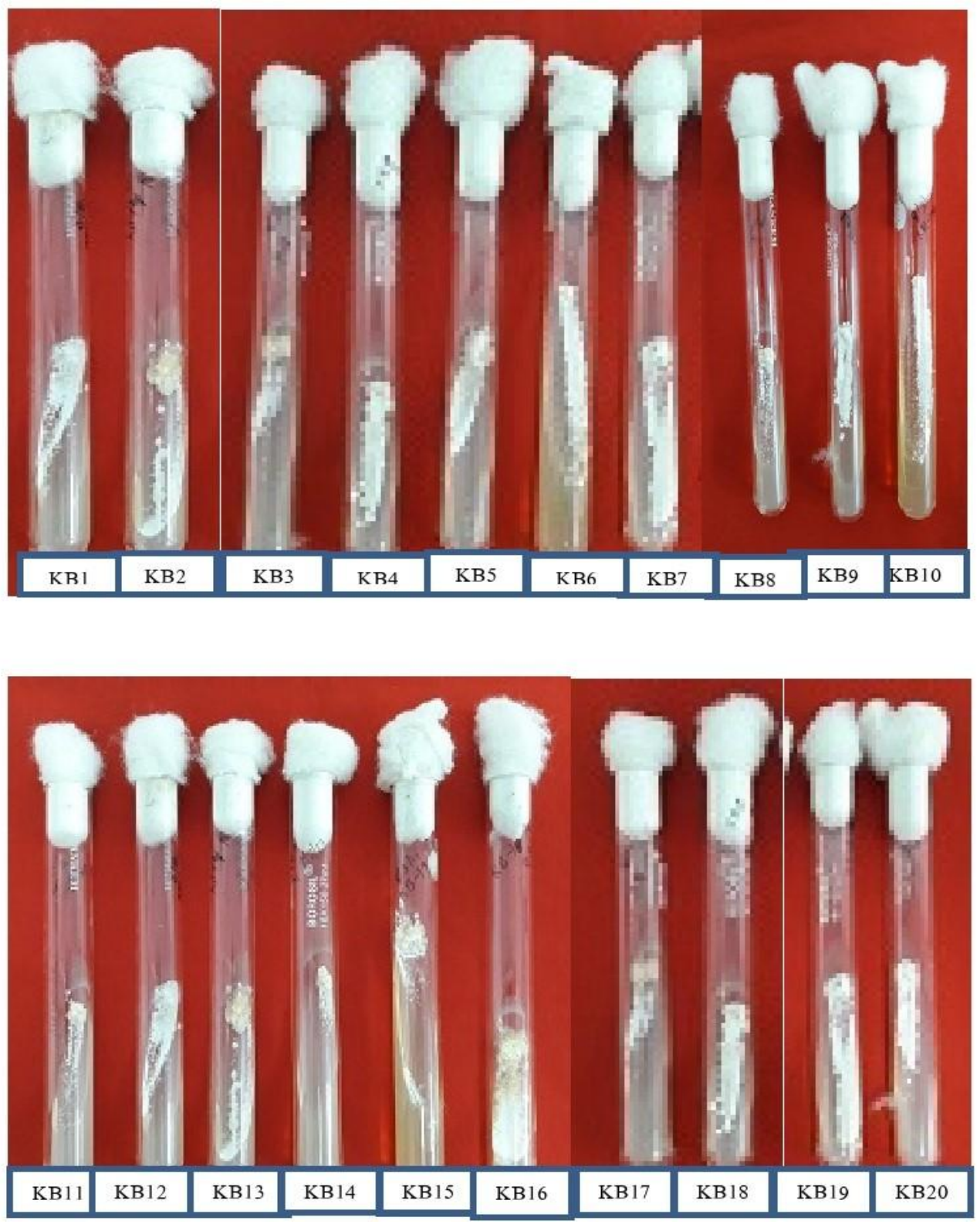

Karnal bunt is an important quarantine disease of wheat not only in India but also in several countries across the world. India being the origin of this disease is targeted more in international wheat trade. The comparative analysis of pathogenic field isolate of $T$. indica from different locations will help in understanding the fungal virulence spectrum.
Selection of effective and sporulative isolate of $T$. indica among 20 isolates was done on the basis of radial mycelial growth, sporulation and mycelial weight. Radial mycelial growth was higher in 6 isolates, with no significant difference between them $(\mathrm{CD}=0.16)$. Allantiod spores which are known for causing infection were counted by 
haemocytometer. KB1 and KB2 isolates were highly sporulating among 20 isolates. Similarly, KB1 and KB2 have higher mycelial weight, when cultured on potato dextrose broth. KB1 and KB2 succeeded in all three parameters with statistically no significant difference between them, when compared with respective critical difference.

When teliospores of T.indica germinate, the single diploid nucleus undergoes meiosis. In general, the colonies of the fungus are brittle, crustaceous, umbonate with wavy margins. Subsequently, from a cushion like structure, two types of secondary sporidia i.e. falcate (allantoid) and filiform sporidia are produced. Most secondary sporidia are mononucleate. Mycelial cells that originate from either type of secondary sporidia are banana shaped, 11.9-13 $\mu \mathrm{m}$ long and 2-2.03 $\mu \mathrm{m}$ wide, and are forcibly discharged. These spores are the only infective entities. The filiform sporidia serve as the reproductive bodies to raise allantoid sporidia in successive generations (Dhaliwal and Singh, 1989).

T. indica is a heterothallic fungus with bipolar incompatibility, controlled by multiple alleles at one locus (Krishna and Singh, 1983; Aggarwal et al., 2010). Bonde et al., (1977) suggested that dikaryotization occurs prior to penetration on glume surface. However, Sharma et al., (2008) have observed that the dikaryotization takes place inside the host tissue. Physiologic forms of $T$. indicaare known to occur in India. Aujla et al., (1987) differentiated four pathotypes K1, K2, K3 and K4 from different regions of Punjab and Himachal Pradesh on the basis of host pathogen interactions on 17 differentials. KB isolates which showed variation in mycelial growth, mycelial weight and sporulation in present study may also differ in their aggressiveness in causing disease on different wheat varieties. So these isolates should be characterized further to know pathogenic variation and thus most virulent isolate obtained should be used for evaluating the breeding material for identifying resistant sources.

\section{References}

Aggarwal, R., Singh, D. V., and Srivastava, K. D. 1999. Studies on ontogeny of teliospore ornamentation of Neovossia indica observed through scanning electron microscopy. Indian Phytopathology, 52(4): 417-419.

Aggarwal, R., Tripathi, A., and Yadav, A. 2010. Pathogenic and genetic variability in Tilletia indica monosporidial culture lines using universal rice primer-PCR. European journal of plant pathology, 128(3), 333-342.

Aujla, S.S., Grewal, A.S. and Sharma, I. 1980. A screening technique for Karnal bunt disease of wheat. Crop Improvement7: 145-146.

Bansal, R., Singh, D. V., and Joshi, L. M. 1983. Germination of teliospores of Karnal bunt of wheat. Seed Research, $11,258-261$.

Bonde, M.R., Berner, D.K., Nester, S.E., Peterson, G.L., Olsen, M.W., Cunfer, B.M. and Sim, T. 2004. Survival of Tilletia indica teliospores in different soils. Plant Disease. 88:316-324.

Bonde, M.R., Peterson, G.L. and Schaad, M.W.1997. Karnal bunt of wheat. Plant Disease 81: 1370-1377.

Dhaliwal, H.S. and Singh, D.V. 1989. Production and inter- relationship of two types of secondary sporidia of Neovossia indica. Current Science 58: 614-618.

Dhaliwal, H.S. and Singh, D.V. 1988. Up-todate life cycle of Neovossia indica (Mitra) Mundkur. Current Science, 57(12): 675-677.

Duran, R. and Cromarty, R. 1977. Tilletia indica: A heterothallic wheat bunt 
fungus with multiple alleles controlling incompatibility. Phytopathology, 67(7): 812-815.

FAO 1996. International Standards for Phytosanitary Measures: Guidelines for Pest Risk Analysis. Rome, Italy: Food and Agriculture Organization of the United Nations.

Gurjar, M.S., Jogawat, A., Kulshreshtha, D., Sharma, S., Gogoi, R. and Aggarwal, R. 2016. Intraspecific variation in Tilletia indica, a pathogen causing Karnal bunt of wheat. Indian Phytopathology, 69(4): 352-356.

Huang, X. Q., and Röder, M. S. 2004. Molecular mapping of powdery mildew resistance genes in wheat: a review. Euphytica, 137(2), 203-223.

Krishna, A. and Singh, R. A. 1983. Cytology of teliospore germination and development in Neovossia indica the incident of Karnal bunt of wheat. Indian Phytopathology, 36(1): 115-123

Mitra, M. 1931. A new bunt on wheat in
India. Annals of Applied Biology, 18(2), 178-179.

Nagarajan, S., Aujla, S.S., Nanda, G.S., Sharma, I., Goel, L.B., Kumar, J. and Singh, D.V. 1997. Karnal bunt (Tilletia indica) of wheat-a review. Review of Plant Pathology, 76(12): 1207-14.

Saharan, M. S., Kumar, S., Kumar, S., Sharma, R., Mahto, B. N., Imtiaz, M. and Joshi, A. K. 2016. Karnal bunt of wheat (Triticum spp.) in India and other South Asian countries. Presented in oral session in XIX International Workshop on Smuts and Bunts held at Izmir, Turkey during May 3-6, 2016: 16-17.

Sharma, I., Sirari, A., Raj, B., Bains, N.S. and Sharma, R.C. 2008. Heterothallism in Tilletia indica: Implications for physiological specialization. Indian Phytopathology, 61:34-42.

Singh, D.V. and Gogoi, R. 2011. Karnal bunt of wheat (Triticum spp) a global scenario. Indian Journal of Agricultural Sciences, 81(1): 3-14.

\section{How to cite this article:}

Jagmohan Singh, Rashmi Aggarwal, M.S. Gurjar, Sapana Sharma and Saharan, M.S. 2018. Characterisation of Isolates of Tilletia indica Inciting Karnal Bunt of Wheat (Triticum aestivum L.). Int.J.Curr.Microbiol.App.Sci. 7(12): 2080-2087.

doi: https://doi.org/10.20546/ijcmas.2018.712.238 